\title{
FAKTOR-FAKTOR YANG MEMPENGARUHI KINERJA USAHA SAPI PERAH RAKYAT DI KECAMATAN GRATI KABUPATEN PASURUAN
}

\author{
. Dimas Pratidina Puriastuti Hadiani ${ }^{l}$. Enike Dwi Kusumawati ${ }^{1}$ dan Rama sukma nurhadi ${ }^{1}$ \\ ${ }^{1}$ Fakultas Peternakan Universitas Kanjuruhan Malang \\ Email: puriastuti@unikama.ac.id
}

\begin{abstract}
Abstrak
Penelitian ini dilaksanakan di Koperasi Usaha Tani Ternak (KUTT) Suka Makmur di Jl. Raya Semambung Grati Desa Grati Kabupaten Pasuruan pada tanggal 1 September 2018 - 25 September 2018. Tujuan penelitian ini untuk mengetahui faktor-faktor yang mempengaruhi kinerja usaha sapi perah rakyat di Kecamatan Grati Kabupaten Pasuruan. Populasi yang digunakan adalah peternak sapi perah yang tergabung di KUTT di Desa Grati Kabupaten Pasuruan dengan alat bantu kuesioner sebanyak 100 orang peternak rakyat yang diambil kepemilikan ternaknya dibawah 5 ekor dan lebih dari 2 ekor sapi perah. Metode penelitian dilakukan dengan metode surve, yaitu mengambil sampel dari populasi peternak sapi perah dengan alat bantu kuesioner sebagai pengumpul data. Hasil dari penelitian ini adalah $\mathrm{Y}=-31,729+0,561 \mathrm{X} 1+5,454 \mathrm{X} 2+2,087 \mathrm{X} 3+$ $1,628 \mathrm{X} 4+8,215 \mathrm{X} 5+(-0,117 \mathrm{X} 6)+0,406 \mathrm{X} 7+(-0,922 \mathrm{X} 8)+0,160 \mathrm{X} 9$ dan nilai R kuadrat sebesar 0,451 hal ini berarti bahwa kinerja usaha sapi perah dapat dijelaskan oleh variable $\mathrm{X}$ sebesar $45,1 \%$ dan sisanya sebesar $54,9 \%$ disebabkan oleh faktor sapilaktasi dan luaskandang. Kesimpulan dari penelitian ini adalah Faktor-faktor yang mempengaruhi kinerja usaha sapi perah di lingkungan peternakan Grati Kabupaten Pasuruan, dari hasil ini variabel yang sangat berpengaruh adalah jumlah sapi laktasi dan luas kandang.
\end{abstract}

Kata kunci : Skala kecil, sapi laktasi

The factors that influence the performance of small scale dairy cattle farm in the sub district of Pasuruan Regency

Abstrak

This research was conducted at the Livestock Farming Cooperative (KUTT) of Suka Makmur on J1. Raya Semambung Grati Desa Grati Pasuruan Regency on September 1, 2018 September 25 2018. The purpose of this study was to determine the factors that influence the business performance of people's dairy cows in Grati District, Pasuruan Regency. The population used is dairy farmers who are members of KUTT in Grati Village, Pasuruan Regency with questionnaires as many as 100 people who take ownership of livestock under 5 heads and more than 2 dairy cows. The research method was carried out by the surve method, which is taking samples from the population of dairy farmers with a questionnaire as a data collector. The results of this study are $\mathrm{Y}=-31,729+0,561 \mathrm{X} 1+5,454 \mathrm{X} 2+2,087 \mathrm{X} 3+1,628 \mathrm{X} 4+8,215 \mathrm{X} 5+(-0,117$ $\mathrm{X} 6)+0,406 \mathrm{X} 7+(-0,922 \mathrm{X} 8)+0,160 \mathrm{X} 9$ and the $\mathrm{R}$ squared value is 0,451 this means that the business performance of dairy cows can be explained by variable $X$ of $45.1 \%$ and the remaining $54.9 \%$ is caused by sapilactation and extensive cage factors. The factors that influence the performance of dairy cows in the Grati farm in Pasuruan Regency, from this result the most influential variable is the number of lactation cows and cage area.

Keyword: small scale, dairy cattle farm

\section{Pendahuluan}

Sapi perah merupakan ternak yang mampu menghasilkan produk susu sebagai produk utamanya. Berdasarkan populasi ternak sapi perah, di Kabupaten Pasuruan, produksi susu sebanyak 19.381.932 liter/ 5th. Situasi produksi susu selama lima tahun terakhir (2003-2007) di Kabupaten Pasuruan mengalami penurunan sebesar 9,25\%, di sisi 


\section{Jurnal Sains Peternakan}

Volume 8 No. 1, Juni 2020, pp:38-40

ISSN 2579-4450

lain untuk populasi meningkat sebesar 3,95\%. Kondisi ini perlu mendapatkan perhatian agar peningkatan populasi ternak diharapkan akan diikuti oleh peningkatan produksi (Anggraeni dan Anneke, 2000). Data primer diperoleh dari wawancara langsung dengan pemilik peternakan sapi perah yang meliputi produksi susu, umur peternak, pendidikan, jumlah anggota rumah tangga, pengalaman usaha, jumlah sapi laktasi, pakan hujauan, pakan konsentrat, curahan tenaga kerja, luas kandang, teknologi (Agustina dkk, 2015). Penyebab penurunan produksi susu disebabkan karena peralatan pemerahan dan peralatan untuk transportasi susu kurang memenuhi persyaratan teknis, kondisi kandang rata-rata relatif kotor, cara pemerahan kurang memperhatikan sanitasi dan higienis produk susu.

\section{Materi Dan Metode}

Materi penelitian yang digunakan adalah Mengetahui faktor-faktor yang mempengaruhi kinerja usaha sapi perah rakyat di Kecamatan Grati Kabupaten Pasuruan selama 25 hari.

Metode Penelitian dilakukan dengan metode survei, yaitu mengambil sampel dari populasi peternak sapi perah dengan alat bantu kuesioner sebagai pengumpul data (Mukson dkk, 2009). Populasi penelitian sapi perah, pengambilan sampel sebanyak 100 orang peternak rakyat. Analisa data dilakukan dengan 3 macam pengujian. Kemudian hasil pengujian di lakukan dengan bantuan aplikasi SPSS for windows

\section{Hasil Dan Pembahasan}

Setelah di lakukan penelitian selama 25 hari diketahui bahwa factor-faktor yang mempengaruhi yaitu factor sapi laktasi dan luas kandang.

\begin{tabular}{lrr}
\hline Variabel & Koefisien Regresi & Sig \\
\hline Umur Peternak (X1) & 0,561 & 0,015 \\
Pendidikan (X2) & 5,454 & 0,492 \\
Anggota Rumah Tangga & 2,087 & 0,651 \\
(X3) & & \\
Pengalaman Beternak (X4) & 1,628 & 0,788 \\
Jumlah Sapi Laktasi (X5) & 8,215 & 0,000 \\
Pakan Hijauan (X6) & $-0,117$ & 0,394 \\
Pakan Kosentrat (X7) & 0,406 & 0,246 \\
Tenaga Kerja (X8) & $-0,922$ & 0,574 \\
Luas Kandang (X9) & 0,160 & 0,000 \\
\hline
\end{tabular}

Faktor-faktor yang mempengaruhi kinerja usaha ternak rakyat di Kecamatan Grati Kabupaten Pasuruan

Berdasarkan tabel di atas terlihat bahwa nilai $\mathrm{R}$ kuadrat sebesar 0,451 hal ini berarti bahwa kinerja usaha sapi perah dapat dijelaskan oleh variable X sebesar 45,1\% 


\section{Jurnal Sains Peternakan}

Volume 8 No. 1, Juni 2020, pp:38-40

ISSN 2579-4450

dan sisanya sebesar 54,9 disebabkan oleh faktor X5 sapi laktasi dan X9 luas kandang. Jumlah sapi laktasi 8,215 dengan tingkat signifikan 0,000 dan luas kendang 0,016 dengan tingkat signifikan 0,000 sangat mempengaruhi kinerja peternak sapi perah rakyat di Desa Grati Kabupaten Pasuruan.

\section{Kesimpulan}

Faktor-faktor yang mempengaruhi kinerja usaha sapi perah di lingkungan peternakan Grati Kabupaten Pasuruan, dari hasil ini variabel yang sangat berpengaruh adalah jumlah sapi laktasi dan luas kandang.

\section{Daftar Rujukan}

Agustina P dkk, 2015. Analisis Faktor-Faktor Yang Mempengaruhi Produksi Susu Sapi Perah Di Kabupaten Karo Provinsi Sumatera Utara

Anggraeni dan Anneke. 2000."Evaluasi Genetik Sapi Perah FH Sebagai Ternak Penghasil Bibit”.Vol 6 No.2.Hal : 149-155. Bogor : Pusat Penelitian Ternak.

Mukson dkk, 2009. Faktor-Faktor Yang Mempengaruhi Kinerja Usaha Ternak SapiPerah Rakyat Di Kecamatan Getasan Kabupaten Semarang. Fakultas Peternakan Uiversitas Diponegoro, Semarang. 